A La aparición del desaparecido. Fotografia familiar y violencia política.

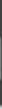

Jorge Moreno Andrés

Artigo recebido em: 23/11/2020

Artigo aprovado em: 21/12/2020 


\title{
A La aparición del desaparecido. Fotografía familiar y violencia política
}

\section{The Appearance of the Disappeared. Family Photography and Political Violence}

\author{
Jorge Moreno Andrés*
}

Resumen: Este texto reflexiona sobre el uso de las fotografias familiares en los contextos de la violencia política en España vinculado a las víctimas del franquismo. Una etnografia sobre las ausencias que busca entender la relación que con los seres desaparecidos ha establecido la familia través del tiempo. Imágenes que incorporan en su materialidad las adherencias de lo secreto y lo querido, la vida insuflada por aquellos que quedaron y que convirtieron los lugares donde las exponían o guardaban en un condensador de memoria.

Palabras clave: Antropología. Memoria. Franquismo. Duelo.

\begin{abstract}
This article explains the use that relatives made of the photographs of the victims of the Franco regime. The proposal is an ethnography on absent beings that seeks to explain the relationship that the family has established with the disappeared over time. This text explains how a photograph can help to replace a body, as a photographic retouch can contribute to being able to perform a funeral ritual.
\end{abstract}

Keywords: Anthropology. Memory. Francoism. Mourning.

* Depto. de Antropología Social y Cultural. Universidad Nacional de Educación a Distancia (UNED). 
Solo de aquello que es simple podemos obtener una infinidad de cosas. (Henri Bergson, Historia de la idea del tiempo, 1902-1903)

Un hombre colecciona incidentes de cosas inexplicables pero ciertas. Para comprobar la veracidad de aquello que colecciona se ve obligado a realizar una investigación en la que hace numerosos viajes. Así comienza una de las escenas de la película El Sacrificio del director ruso Andréi Tarkovsky. Uno de los incidentes que forma parte de la colección que realiza el personaje de ese film está directamente relacionado con fotografías vinculadas a contextos bélicos. Como aquella de Königsberg en la que una madre le pide a su hijo que se hagan un retrato. Él tiene 18 años y lo acaban de llamar para alistarse en la Segunda Guerra Mundial. Unos días después de estar en el frente, el hijo muere y la madre abandona la ciudad para estar lejos de los recuerdos, olvidándose por completo de recoger aquel retrato que había encargado. Al cabo de unos años, en 1960, la mujer fue a un fotógrafo para hacerse un retrato que quería enviar a una amiga. Sin embargo cuando fue a recoger las copias vio que no estaba solo ella, sino que su hijo muerto también aparecía con el uniforme y la edad que tenía cuando se hizo aquella fotografía que nunca recogió. Ella sale en 1960 y él en 1940. “Además tengo una copia del certificado de nacimiento del hijo y una compulsada del parte de defunción. Tengo unos 300 incidentes similares, 284 para ser exactos. Simplemente estamos ciegos. No vemos nada", concluye el protagonista de esa escena.

Hubo una fotografía que quedó también abandonada en un pueblo de Extremadura durante los años cuarenta en España. La 
escena es narrada por María de la Luz Mejías Correa (2006) en su libro Así fue pasando el tiempo. En esas memorias relata el suceso de un retrato que, como en la película de Tarkovsky, nunca fue recogido por la madre del soldado. En aquella fotografía aparecía su hijo Juan junto a su nuera María de la Luz, y la muerte que provoca el abandono de la imagen no es la del soldado, sino la de la propia madre que fue fusilada y nunca pudo recoger el encargo. Aquella imagen apareció un tiempo después en la casa de Juan y María de la Luz, pues el fotógrafo decidió buscar a la mujer que había encargado el retrato. "Después del fusilamiento", señala María, "vino el pobre hombre preguntando por mi suegra para entregarle el trabajo. Cuando se encontró a la familia destrozada, el fotógrafo dejó el retrato y se marchó sin cobrar nada por ello. Yo todavía conservo el retrato colgado en la pared de mi casa" (MEJÍAS CORREA, 2006, p. 65).

Si en el primer caso la aparición del ausente está contenida en la imagen misma, en este caso la aparición la contiene el encargo, pues esa es la historia que evoca el retrato cada vez que María de Luz lo mira. Para la familia que observa esa fotografía, quien aparece no es tanto lo que está presente en la imagen como el ser ausente que de alguna manera lo contiene. Cualquier persona que no conociera lo sucedido y mirara la imagen únicamente podría sacar el sentido de la apariencia, de la superficie, algo que en realidad poco nos tiene que decir sobre la importancia de dicho retrato. Como dice el personaje de El Sacrificio: "Simplemente estamos ciegos. No vemos nada". Observar una fotografía familiar, sin el contexto doméstico que le da sentido es aprehenderla siempre a medias. Las herramientas que proporciona la antropología posibilitan sin embargo la conversación con los poseedores de las imágenes para analizar sus discursos 
y observar sus prácticas. Se trata con ello de situar el sentido de un objeto en los términos mismos de la importancia que tuvieron para quienes los poseen y los usan, para quienes los cuidan o los descuidan.

A diferencia de las 284 imágenes que recoge el personaje del film, yo he acumulado más de 2.000 fotografías en una investigación de largo recorrido sobre las víctimas del franquismo. Un estudio que se interroga por la memoria objetivada en los retratos familiares, cuando éstas transitan por un contexto de violencia política. Las fotografías, como la memoria, se encuentran en continuo movimiento, dibujando recorridos inesperados, acudiendo allí donde es necesario estrechar un vínculo, un vínculo establecido siempre por personas ausentes que son la explicación de la condición bajo la que viven los miembros de una casa. El sentido por tanto de la imagen no está en la fotografía en si, sino en la pragmática del objeto, en los encargos, cuidados, herencias, amputaciones o enmarcados que hacen las personas con los retratos a lo largo del tiempo. Mi propuesta es por tanto la de una etnografía cuyo objeto de sentido son fotografías. Una etnografía sobre ausencias que busca entender la relación que con los seres desaparecidos ha establecido la familia través de imágenes. Los materiales son restos, rastros, huellas... apariciones. Los protagonistas son seres ausentes, fantasmas, gente que en lugar de entender que su misión era desvanecerse en la nada, han decidido no morirse. Como aquel soldado que apareció en la fotografía de Königsberg.

Para analizar estas imágenes, sustituimos la idea de que la semiótica se funda en la existencia de un código por la idea de que se origina en la existencia de un interpretante. En la acción de una 
mujer que coloca a su hijo en una foto haciendo una composición, lo que el objeto evoca no es solo al hijo, es también el dolor de ella, y lo que fundamenta el acento del etnógrafo es la interpretación de la acción de esa mujer. No me interesa, por tanto, el referente como problema significativo en semiótica, pues la mayoría de los procesos semióticos que producimos no tienen un referente, no hay referente en ellos; lo que hay son objetos que se construyen a partir de interpretaciones. En un análisis etnográfico e historiográfico basado en documentos visuales, esta cuestión puede resultar muy insidiosa, porque todo el rato se está haciendo referencia al tema de la verosimilitud referencial de esas imágenes, un problema que para este análisis resultaría inútil, pues aquí lo que cuenta es lo que hacen las personas al construir signos, es decir, al manipular y producir una pragmática con esas imágenes. Esos desplazamientos vitales (APPADURAI, 1986) que sufre una fotografía produce sentidos que no siempre se explican o teorizan sino que simplemente se practican. La memoria no es una foto fija, como así son los hechos con los que la historia describe un suceso pasado. La memoria son fotografías en movimiento, recuerdos con duración. Y para poder examinar la memoria que la fotografía objetiva, los recuerdos con duración inscritos en la materialidad misma, hay que situar el análisis de la imagen siempre en las variables de espacio y tiempo.

1) El tiempo inscrito en el movimiento que desplaza la fotografía y que lleva a preguntarnos por las diferentes ubicaciones por las que ha transitado así como por las personas que la poseen, la heredan o la entregan.

2) El tiempo inscrito en la materialidad del objeto mismo 
y que lleva a preguntarnos por los usos que se le ha dado a la fotografía (desgastes, arrugas, recortes, ampliaciones, enmarcados, escritos, etc.).

3) El tiempo inscrito en las historias que se cuentan cuando se mira una imagen. La manera de introducir el tiempo en el espacio se produce a través del relato, a través de las historias que solo conocen los poseedores de las fotografías y que nos hablan de la importancia de ese objeto.

La ausencia del hijo muerto está ahí. Siempre ha estado, aunque se aleje. Es lo que parece decir el director ruso con aquella escena. No es casual tampoco que la colección fotográfica que recoge ese personaje del film esté vinculada a la Segunda Guerra Mundial, un contexto generador de ausencias momentáneas y definitivas que son sustituidas por los cuerpos fotográficos. En esas situaciones bélicas, generadoras de inquietud, se intenta compensar la angustia con fotografías familiares que el soldado guarda en el frente ${ }^{1}$ o que la familia conserva en la casa mientras dura ese periodo. Las muertes que traiga la guerra convertirán los retratos de soldados en imágenes de muertos. Ese es el tipo de colecciones fantasmagóricas que parece haber recogido el personaje de la película El Sacrificio, unos retratos muy similares a los que yo he recogido y analizado para el caso español.

En muchas de ellas hay un elemento común a la de Königsberg pues el ausente aparece siempre como una especie de fantasma

1 En la reciente película de San Mendes que lleva por título 1917, hay una escena donde uno de los soldados protagonistas, en el momento en que ha recibido un disparo y está a punto de morir, saca un retro que lleva en el bolsillo y lo besa. La cámara entonces retrocede y vemos al soldado muerto sosteniendo en su último aliento la imagen de su familia. 
pegado al cuerpo de los vivos. Pegado a la imagen, pero también pegado a la alcoba, al salón o al bolsillo. Imágenes que como en el caso de los dos encargos descritos más arriba son hechos siempre por mujeres, pues son ellas las que tradicionalmente han ordenado la economía de la mirada de una casa, son ellas las curadoras del espacio doméstico, las que eligen qué imagen del álbum se cuelga en la pared, qué fotografías uno mira cuando entra en la casa, cuáles se ocultan o cuáles te acompañarán toda la vida. En el caso de las víctimas de la represión franquista es fundamental entender el binomio fotografía/espacio doméstico pues la imposibilidad de realizar un ritual funerario por la desaparición del cuerpo, hizo que las familias tuvieran que sustituir las prácticas normativizadas de un entierro por otras diferentes subsumidas a un contexto siempre cercenado, como es el de la casa. Un contexto en el que tuvieron que inventar fórmulas de disimulo con las que preservar una memoria perseguida y eliminada.

Si observamos la siguiente fotografía podemos imaginar que una parecida podría formar parte de la colección que aglutinó el personaje de El Sacrificio. En este caso quien aparece es el padre de los hijos, un muerto que flota como un fantasma por encima de los vivos. Para forzar la aparición la familia tuvo que realizar una búsqueda previa. Es por ello que al enterarse del asesinato de Alfonso Capilla, el hermano fue al lugar donde estaba el único cuerpo al que la familia podría acceder: la foto pegada en su carnet de minero. Cuando la imagen apareció en la casa, aquellos tres centímetros arrancados a la tarjeta de identificación laboral, estaba llegando el cuerpo pues fue el momento en el que los lloros por el duelo se hicieron más presentes. Esa pequeña imagen realizada para registrar 
al minero en su lugar de trabajo era el lugar más nítido donde se podía objetivar el lugar que a partir de ese momento debería ocupar el difunto en la vida de los descendientes. Fue por ello que la hermana del difunto encargaría este retrato donde aparece el desaparecido como una especie de ente protector sobre sus hijos. Al contrario que en la película de Tarkovsky, aquí el aparecido no aparece por decisión propia sino por invocación familiar, pues el sacrificio que implicaba ampliar su figura y convivir con los muertos suponía una posibilidad de permanencia, una lucha descarnada pero silenciosa contra la máquina del olvido que implicaba el régimen franquista.

Fig. 1 - Composición fotográfica de Alfonso Capilla e hijos

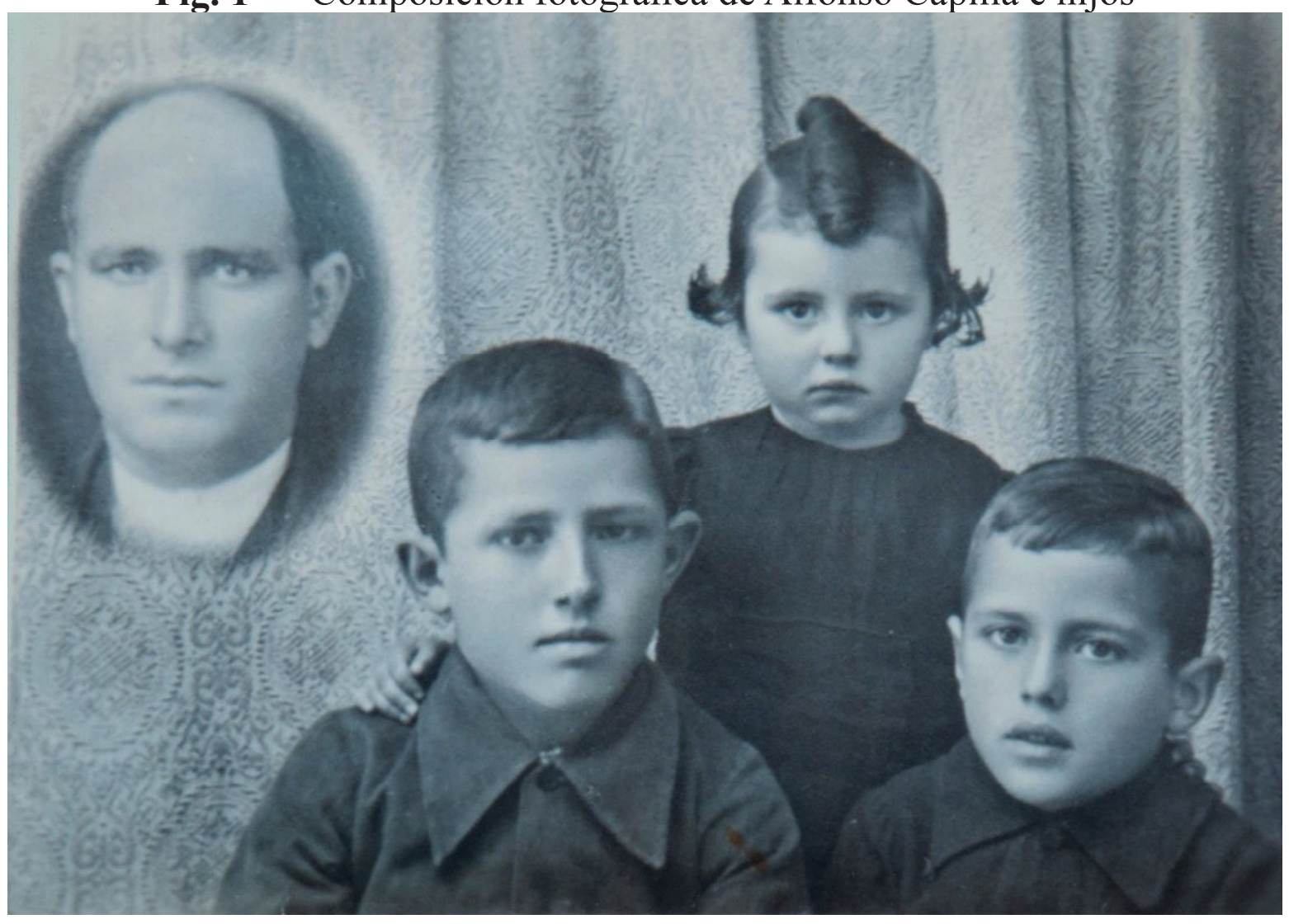

Fuente: Colección particular de la familia Capilla

Pensemos ahora en otra película, esta vez la de Eternal Sunshine of the Spotless Mind del director francés Michel Gondry. 
El protagonista de este largometraje acude a una empresa para que le borren los recuerdos de la novia con la que acaba de romper. Sin embargo, cuando la máquina del olvido comienza el borrado, éste se arrepiente. Será entonces cuando él intente desesperadamente, en el interior de sus propios recuerdos, preservar la memoria de ella. Esa es la manera en que él la escamotea de la máquina del olvido, escondiendo a la amada en aquellos recuerdos donde no pueda encontrarlos, aquellos lugares de la infancia situados en las partes más profundas de la memoria y donde en realidad ella no debería de estar. De una manera similar, las mujeres que preservaron la memoria de las víctimas del franquismo tuvieron que esconder en los rincones más profundos de la casa a los seres más queridos para que la máquina del olvido no los encontrara.

Muchos de los encargos fotográficos realizados por estas mujeres implicaban en realidad un gesto radical, un gesto que en la película de Tarkovsky aparece de manera involuntaria, pero que aquí se convertía en una necesidad: hacer aparecer al desaparecido. Para ello debemos de imaginar precisamente una especie de procesión de mujeres de negro, caminando silenciosamente hacia una tienda de retratos sosteniendo entre sus manos una de las pocas fotografías que quedaban del difunto ${ }^{2}$. El fotógrafo se encuentra con el problema técnico que supone ampliar apenas un centímetro de cabeza de una diminuta fotografía a un tamaño casi natural para un cuadro que la familia quería poner en la alcoba. Esto le obligaba a recurrir a aquella técnica usada por los pictorialistas de principios del XX y que

2 Generalmente se trataba de una pequeña imagen con la que querían hacer una gran ampliación y que había sido realizada en los momentos de festividad de un pueblo, cuando junto a otras atracciones llegaba el fotógrafo. Hay que pensar que las clases populares estaban accediendo por primera vez a la posesión de imágenes en esa época, por tanto las imágenes de los ausentes que tenga las familias, y a las que yo accedo, serán por lo general de una o dos fotografías. 
llevaba por nombre bromóleo. Una técnica consistente en hacer una copia en un papel que pueda ser pintado para repasar con pincel el desvanecimiento de la fotografía, pues la ampliación implicaba una pérdida de nitidez y forma. La solución son fotografías pintadas que acentúan con ese carácter híbrido, mitad pintura-mitad fotografía, una apariencia fantasmal.

Fig. 2 - Composición fotográfica de Rafael León junto a sus hijos Rafael y Ceferino.

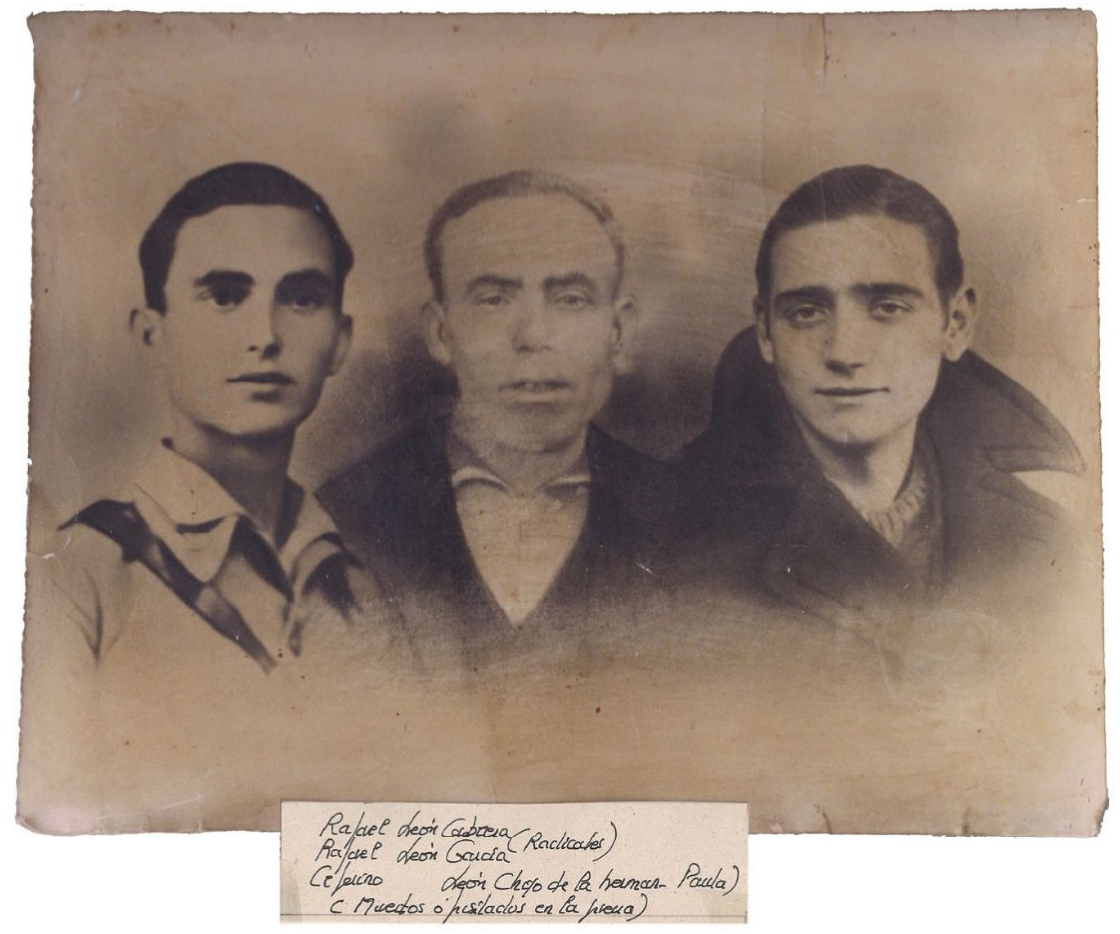

Fuente: Colección particular de la familia León.

Esas pequeñas imágenes que quedaron, y que las mujeres llevaban para realizar los encargos, están llenas de inscripciones en sus reversos. Están llenas de capas temporales en las que una dedicatoria se mezcla con numeraciones e instrucciones, un espacio donde el "para mi querida esposa" aparece unido a las medidas que el fotógrafo estaba anotando para su ampliación. Inscripciones en las que aparece el retoque que la nueva imagen incorpora y que en unos 
casos se presenta como una aparición sobre los hijos, y otras en las que el aparecido lleva traje y corbata. La incorporación en la nueva imagen de un traje objetiva en realidad la colocación de una mortaja que era la ropa que se hubiera puesto al cuerpo real si se le hubiera hecho un ritual funerario. En el encargo fotográfico se produce por tanto un desplazamiento para que eso siga ocurriendo, y en ausencia de cuerpo físico el traje se le incorpore al cuerpo fotográfico. Una vestimenta que no recuerdan que esa elegancia no desaparecerá en un ataúd sino que estará siempre visible en el salón o en la alcoba de la casa. Y es que si el cuerpo fotográfico sustituye al físico, las casas son al mismo tiempo la transferencia de los sepulcros. Una especie de tumba donde permanecerá colgado el único cuerpo visible de alguien cuyos restos están en paradero desconocido.

Fig. 3 - Anverso y reverso de la fotografía Santiago Ruiz Mora
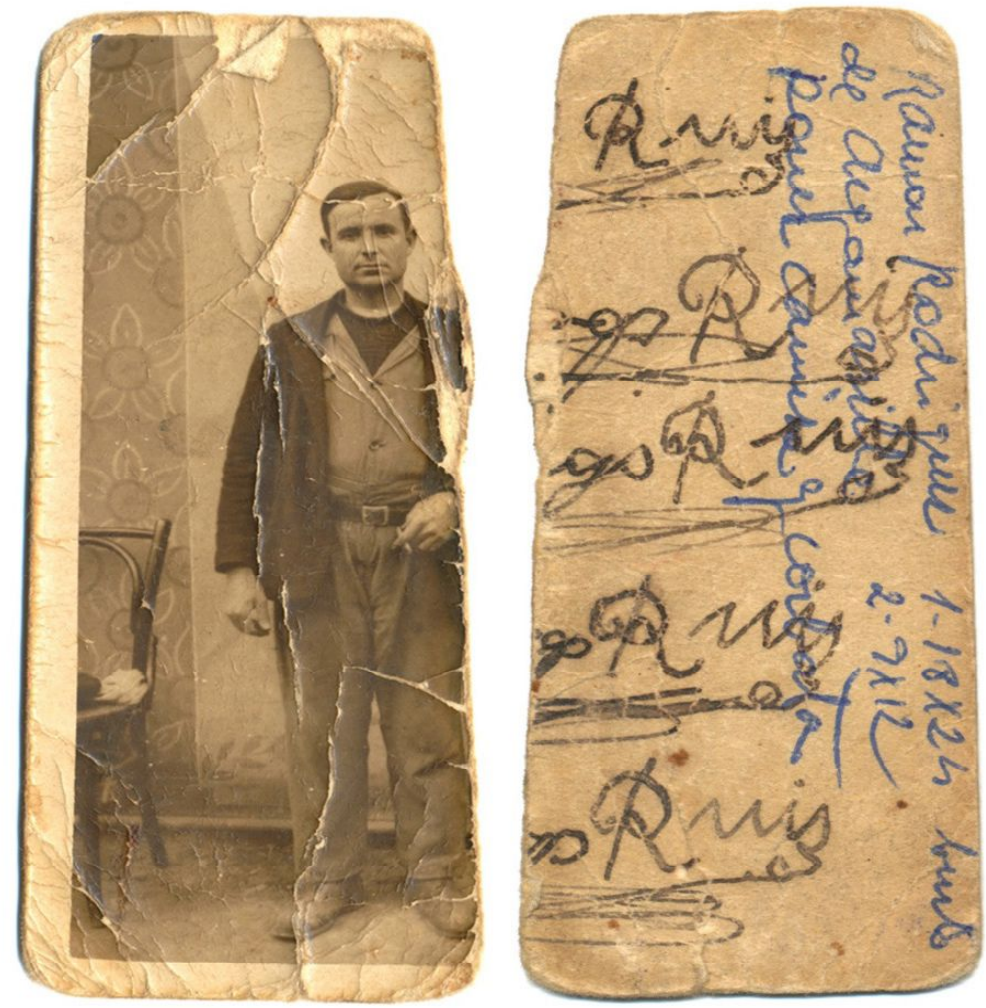

Fuente: Colección particular de la familia Ruiz. 
Unas semanas después de aquel encargo la mujer regresa de nuevo a la tienda para recoger la imagen. En ese momento el fotógrafo extiende en el mostrador el retrato cubierto con un papel cebolla. La escena nos recuerda a la de una morgue en la que alguien va a reconocer un cadáver. La madre quita ese papel o sábana que cubre el cuerpo y entonces ve aparecer allí, en una tienda de fotos, a su hijo desaparecido... y rompe a llorar.

Era un momento muy especial. Ver llorar a las mujeres ante una imagen de aquellas era muy impactante, al menos para un niño que no está acostumbrado a que vaya la gente a hacerse una foto y que lo normal es que te digan qué mal he salido, qué guapa he salido. Pero aquel sentimiento que se volcaba en un momento determinado sobre una imagen... Porque en otras circunstancias se podian cabrear porque me gusta o no me gusta. Pero aquí afloraban otras historias que ellas sabrian, a nosotros no nos competía el meternos en la historia de nadie. Pero sí que, si que pasaban como una frontera donde los sentimientos brotaban de una manera absolutamente natural y desbordada. De la misma manera que nos parecían fotos de muertos, aquellos momentos eran, eran momentos muy impactantes ${ }^{3}$.

3 Entrevista realizada a Luis Morales (Ciudad Real, 19/12/2016). 
Fig. 4. - Fotografía original y bromóleo de Julián Gómez
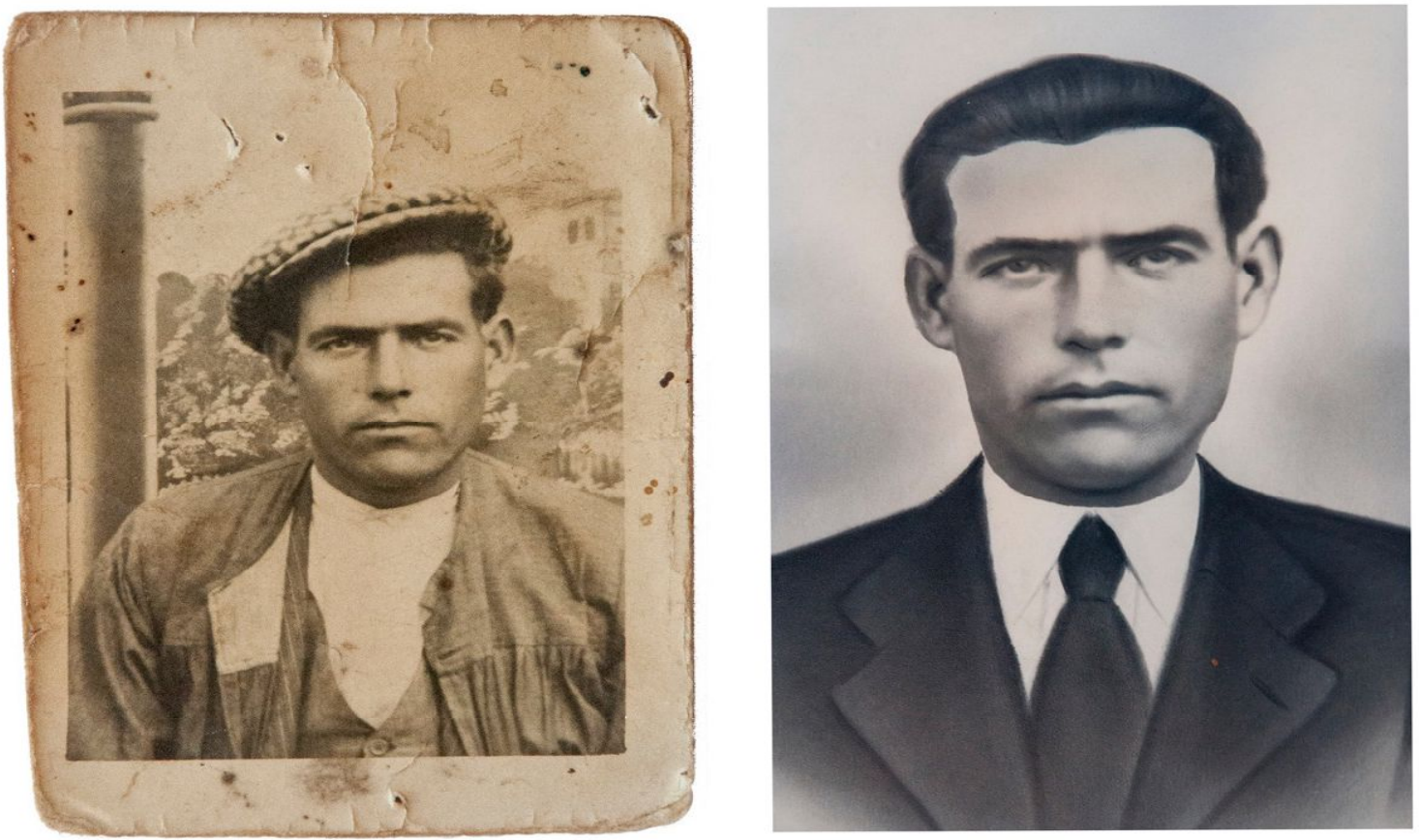

Fuente: Colección particular de Vicenta Ruiz

Todo ritual implica siempre una transformación. En el caso de los funerarios, la conversión de alguien que está vivo en alguien que está muerto. Hay que recordar que "estar" muerto es también una manera de "estar" en el mundo y que generalmente las relaciones sociales que se establecen con los difuntos suponen una serie de prácticas que no solo están relacionadas con el cuidado y las visitas a las tumbas de nuestros seres queridos, sino con un elenco mayor de comportamientos vinculados primeramente a un proceso de duelo y posteriormente a una relación alargada con los antepasados. La conversión en antepasado es precisamente lo que está mediando constantemente en los rituales de muerte ${ }^{4}$, y la imposibilidad de completar ese ritual, cuyo objetivo es trasladar 4 Esto es algo que se da de manera más evidente en sociedades no secularizadas, como afirmaba el antropólogo Caro Baroja cuando señalaba que "son las sociedades rurales no secularizadas las que tienen dos clases de componentes: los vivos y los muertos" (CARO BAROJA, 1979, p. 71). 
al difunto al mundo de los muertos, sitúa al ausente en una espera permanente, como si la barca de Caronte hubiera quedado encallada en mitad de la laguna estigia y el difunto estuviera atrapado entre dos mundos. Una desorientación que el régimen franquista provocaba en las familias mediante el terror y el miedo no solo del asesinato sino en la ocultación de los cuerpos. Ese estado liminal en el que se encuentran los desaparecidos, ese no estar ni en un sitio ni en otro, ese fantasma que vaga buscando un destino es solucionado por las familias dándoles una orilla donde recaer. Como si con su esfuerzo consiguieran empujar aquella barca encallada, una barca cuyo destino será precisamente el mismo que buscara Ulises: su oikos. Pues el lugar que instauran las fotografías y que supone el elemento central de la nueva convivencia con el ausente no es el cementerio sino la casa.

Es en esos gestos donde las familias se están jugando el tipo, pues de ellas dependen que el desaparecido, que no está en ninguna parte, no se desvanezca en la nada sino que se haga presente, que tenga un lugar. El drama es por tanto el de cargar con el muerto, una situación a la que se ven abocadas las familias para incidir con sus esfuerzos en una existencia que puede desaparecer sin dejar rastro. El sacrificio de estas personas está precisamente en ese punto, en el de asumir la carga de un muerto con su propia vida, algo que a todas luces es una situación dramática y que la película Dead Man del director estadounidense Jim Jarmusch parecía indicar con la frase que da inicio al film: "es preferible no viajar con un hombre muerto". Sin embargo, para poder viajar con un hombre muerto las familias tuvieron que convertir una fotografía profana en un retrato sagrado, a la manera de un tesoro al que solo algunos de la casa iban teniendo acceso. Imágenes que incorporan en su materialidad las adherencias 
de lo secreto y lo querido, la vida insuflada por aquellos que quedaron y que convirtieron los lugares donde las exponían o guardaban en un condensador de memoria que estiraba la vida de los ausentes en la cotidianidad de los presentes. Una relación intensa que se puede observar en las arrugas de una fotografía tantas veces besada, tantas veces guardada. Una relación que desplaza la memoria vivida por la memoria transferida en una lucha soterrada contra el tiempo histórico que el franquismo intentaba imponer ${ }^{5}$.

\section{Escena final}

"Un regalo implica siempre un pequeño sacrificio", se señala en un momento de la película de Tarkovsky para explicar con esa frase el título de su último film. Es por ello que el largometraje gira en torno a un cumpleaños, una fiesta donde el coleccionista al que nos hemos ido refiriendo en el texto regala al protagonista de la película el cuadro la Adoración de los Magos de Leonardo da Vinci. La revelación que supone para muchas mujeres contar a los descendientes que van naciendo la situación real que vive la familia, la marginación vinculada al asesinato de alguno de sus miembros, se parece a la revelación que se hace a los niños cuando llega el 5 Afortunadamente, la gente nunca es solo el objeto pasivo de la historia. Y a parte del heroísmo popular, existe también la ingenuidad popular. En este caso, esa ingenuidad utiliza lo poco que esté a su alcance para recrear un área de «intemporalidad», para insistir en lo permanente. De este modo, centenares de millones de fotografías, imágenes frágiles, que a menudo se llevan cerca del corazón o se colocan junto a la cama, son utilizadas para que hagan referencia a lo que el tiempo histórico no tiene derecho a destruir. La fotografía privada es tratada $\mathrm{y}$ valorada hoy como si fuera la materialización de esa mirada desde la ventana, a través de la historia, hacia aquello que estaba fuera del tiempo (BERGER, 2007, p. 108). 
momento de contarles que los Reyes Magos son los padres. Todo ritual implica una transformación, un tránsito que coloca al neófito en el grupo de los que conocen el secreto y que lo segregan de los que lo desconocen. La revelación, el conocimiento de una información, es lo que lo introducen en el nuevo grupo. De alguna manera eso pasó con muchas familias que en un determinado momento decidieron contar a sus descendientes algo de lo que no se hablaba fuera ni tampoco dentro de sus casas. Un secreto que revelaba la condición de la familia y que se objetivaba en la veneración de fotografías expuestas y en el cuidado de tesoros ocultos.

La escena final de la película El Sacrifico termina con el regalo que un padre le deja a un hijo después de su muerte, un ritual basado en la historia en la que un monje planta un árbol seco y le encarga a su discípulo regarlo todos los días. Después de tres años el árbol muerto floreció. El regalo consiste precisamente en eso, un gesto aparentemente inútil que el director de la película le está dejando a su hijo, pues el film está dedicado a él "con confianza y esperanza”. Eso es precisamente lo que harán las familias con los retratos encargados y expuestos, forzar la aparición del desaparecido insuflando vida en una naturaleza muerta, colocando un retrato en el centro en torno al que gira el sentido de una casa, un ser muerto al que se le habla, se le besa o se le abraza hasta el punto de hacerlo florece. Es por ello que algunos nietos como Carmen Mancha ${ }^{6}$ señalaban que gracias a eso su abuela consiguió enseñarle a querer a un abuelo que nunca conoció. Eso es algo que quedara patente en las fotografías que quizá más se parezcan a las descritas en la película de El Sacrificio, aquellas donde se juntan dos tiempos claramente diferenciados y que fueron

6 Entrevista realizada a Carmen Mancha (Madrid, 02/07/2016). 
encargadas por los descendientes cuando la viuda murió ya anciana y la incorporaron en el nuevo retrato junto al joven desaparecido. Para algunos hijos, nietos y sobrinos, la muerte de madres, abuelas o tías, significó de alguna manera la segunda muerte del padre, pues fueron ellas precisamente las que con su esfuerzo mantuvieron viva la presencia de aquel ser querido que nunca conocieron pero al que amaron profundamente.

Fig. 5. - Benita Lillo y Anastasio Godoy

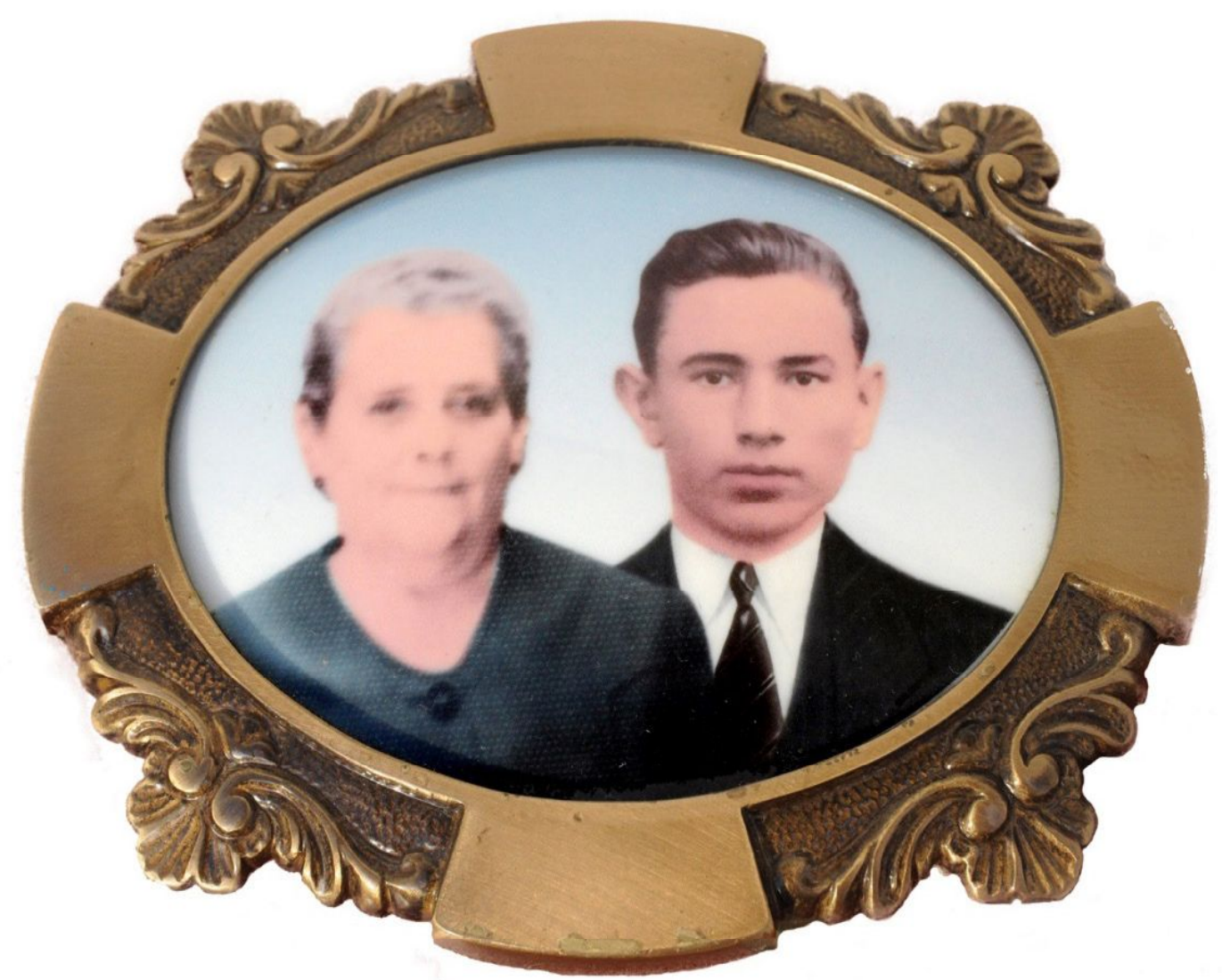

Fuente: Colección particular de la familia Mancha Godoy. 


\section{Referências}

APPADURAI, Arjun. The social life of things: commodities in cultural perspective. Cambridge: Cambridge University Press, 1986.

BERGER, John. Otra manera de contar. Barcelona: Gustavo Gili, 2007.

BERGSON, Henri. Historia de la idea del tiempo. Barcelona: Paidós, 2018.

CARO BAROJA, Julio. Ensayos sobre la cultura popular española. Madrid: Dosbe, 1979.

MEJÍAS CORREA, María de la Luz. Así fue pasando el tiempo. Sevilla: Renacimiento, 2006.

MORENO ANDRÉS, Jorge. El duelo revelado. La vida social de las fotografías familiares de las víctimas del franquismo. Madrid: CSIC, 2018. 